\title{
Enhancing Performance in Co-curricular Activities Through Structured Approach in Minor Projects
}

\author{
Shivaraj.Hublikar ${ }^{1}$, Uma Mudengudi ${ }^{2}$, Priyatam Kumar ${ }^{3}$, \\ Rajashekar B. Shettar ${ }^{4}$, Arun Kakhandki ${ }^{5}$, Soumya S Patil ${ }^{6}$ \\ $1,2,3,4,5,6$ Department of Electronics and Communication Engineering \\ KLE Technological University, B. V. Bhoomaraddi College of Engineering \& Technology, \\ Hubli, Karnataka, India \\ 1'shivaraj@bvb.edu, ${ }^{2} u m a @ b v b . e d u,{ }^{3}$ priyatam@bvb.edu, \\ ${ }^{4}$ raj@bvb.edu, ${ }^{5}$ arun@bvb.edu, ${ }^{6}$ soumya@bvb.edu
}

\begin{abstract}
This paper discusses the process of enhancing the student's performance through minor project. Minor projects are typically carried out in third year of four year engineering graduation. In this paper the rubrics based evaluation is defined to enhance the minor project experiences. Minor projects are one of the platform to showcase integrated learning experience. The defined rubrics are based on engineering design process. The experiment is done on 2012-2016 batch of 6th semester students. Performances of the students are show- cased through co-curricular activities and by participating in various competitions held across the country. With this practice achievement in cocurricular activity participation is increased from $15 \%$ to $65 \%$ for previous year batch.
\end{abstract}

Key words: minor project, co-curricular activities, ABET criteria.

\footnotetext{
Shivaraj Hublika

Department of Electronics and Communication Engineering KLE Technological University, B. V. Bhoomaraddi College of Engineering \& Technology, Hubli, Karnataka, India shivaraj@bvb.edu
}

\section{Introduction}

This paper addresses a process to enhance the performance of student's in minor projects. Projects are the integral part of any engineering program where in students realize the innovative idea into working model or provide the solutions to the engineering problems, by applying the knowlede or skills aquired during previous semister. Minor projects are one of the tool to showcase the integrated learning environment[1-4]. The credits for minor project is 6 for the 2012-2016 batch. Theme is defined for the students to select the problem statement under different application areas. Engineering design and Project life cycle is followed during implementation of the project. In engineering design process the basic sciences, mathematics and engineering sciences are applied to convert an idea into a process or a product. The project is carried out under four stages. They are initiation, planning, execution and closure.

Evauation of the project is done through well defined rubrics. The rubrics for minor projects are designed as per engineering design process. Rubrics helped project guides in assessing the knowledge and skills aquired by the students. Projects are reviewed by the respective guide, and department expert review commitee formed by the Head of Department. Evaluation of the projects are carried out under 4 reviews. Projects are reviewed by respective guide, once in a week and a department commitee will review once in month. Students are encouraged to participate in co- curricular activities. Performance of 
the students are showcased through co-curricular activities. This paper describes the excecution of minor projects for the third year students in electronics and communication engineering curriculum[5-11].

The organization of the paper is as follows. Section 2 describes the various stages in the implementation of minor projects. Sections 3 describes the evaluation scheme. Section 4 discusses the outcomes and finally the conclusions.

\section{Minor Projects}

The students are given with theme to select the problem statement. The theme given in third year is "Sense, control, Act: Measure the universe, Transform the world..." The objective of the project is to sense the data, process it and take decision based on the chosen application. The application areas are defined as:

I. Automotive - This area is chosen as it is an emerging field for the years ahead.

II. Assistive Technology - To aid the people with disabilities.

III.Medical - To design a cost effective solution for health related problems.

IV. Very Large Scale Integrated circuit (VLSI) - To design analog circuits.

In the category 1, 2 and 3 the students are using the sensor from the mobile phone and developing the application on android platform.

In order to carry out the project in android the students need to have knowledge of courses like engineering physics, mathematics, analog electronics, Microcontroller, signals and systems, HDL, communication and programming concepts of HDL, $\mathrm{C} / \mathrm{C}++$.

\subsection{Guide lines for selection of a project}

The following guidelines are set for the selection of problem statements

i. The project needs to encompass the concepts learnt in subject/s studied in the previous semesters, so that the student will learn to integrate the acquired knowledge to provide a solution to the defined problem statement for the mini-projects. ii. Student can select a project which leads to a product or model or prototype. The selected project should cater to the blocks mentioned in the Figure 1.

iii. Time plan: Effort to do the project should be between 120-150 Hrs per team, which includes self study of an individual member (80-100 Hrs) and team work (40-50hrs).

iv. Learning overhead should be $20-25 \%$ of total project development time.

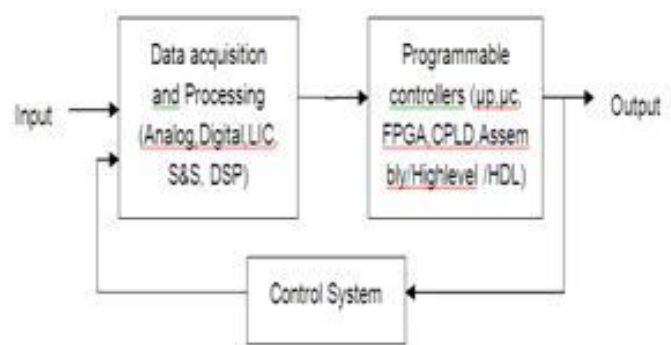

Figure 1: Block diagram of project problem statement

\subsection{The project life cycle}

Figure 2 shows the project life cycle. This includes,

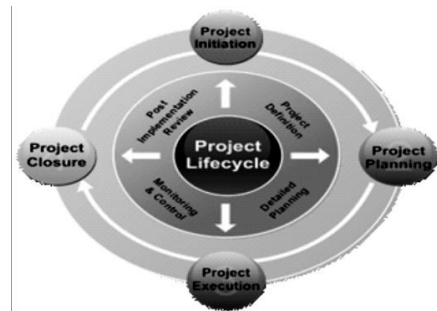

Figure 2 : The minor project life cycle [7]

Project initiation-This is the critical phase within the project life-cycle. It is also called the project preplanning phase of the selected problem statement and work with multiple solutions. Here the project scope is defined and the appropriate methods for completing the project are determined.

Project planning-This is a part of project management which relates to the use of schedules to plan and subsequently report progress within the project environment.

Project execution-This involves systematic execution of project plan.

Project closure-This phase deals with the releasing of final deliverables, handing over the project documentation, writing technical papers is carried out. 
Table 1: Mapping of a-k and evaluation rubrics for CIE marks

\begin{tabular}{|c|c|c|c|c|c|c|c|}
\hline Review & $\begin{array}{l}\text { Sl. } \\
\text { No }\end{array}$ & Description & Marks & $\begin{array}{l}\text { Inadequate } \\
\text { Upto } 25 \%\end{array}$ & $\begin{array}{l}\text { Average } \\
\text { Upto } 50 \%\end{array}$ & $\begin{array}{l}\text { Admirable } \\
\text { Upto } 75 \%\end{array}$ & $\begin{array}{l}\text { Outstanding } \\
\text { Upto } 100 \%\end{array}$ \\
\hline \multirow{7}{*}{ 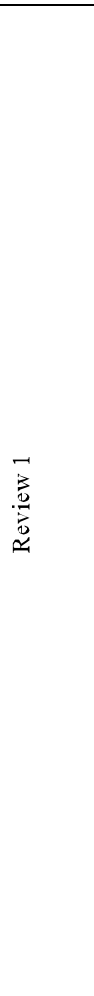 } & 1. & $\begin{array}{l}\text { Need Analysis } \\
\text { ECOE(e)-1A }\end{array}$ & 3 & Not done & Not well defined & Framed but not clear & Need analysis done. \\
\hline & 2. & $\begin{array}{l}\text { Identify the } \\
\text { Problem } \\
\text { ECOE(e)-1D }\end{array}$ & 2 & $\begin{array}{l}\text { Objectives are not } \\
\text { clear. }\end{array}$ & $\begin{array}{l}\text { Objectives and scope } \\
\text { are not well defined. }\end{array}$ & $\begin{array}{l}\text { Objectives clearly framed. } \\
\text { Scope not well defined. }\end{array}$ & $\begin{array}{l}\text { Objectives are correctly } \\
\text { stated. }\end{array}$ \\
\hline & 3. & $\begin{array}{l}\text { Understanding of } \\
\text { professional ethics } \\
\text { Copy right, } \\
\text { plagiarism } \\
\text { ECOE(f)-2A,2B }\end{array}$ & 2 & Not read & $\begin{array}{l}\text { Read but not } \\
\text { understood }\end{array}$ & Read and understood & Read, understood \\
\hline & 4. & $\begin{array}{l}\text { Problem definition } \\
\text { and } \\
\text { Application in } \\
\text { societal contest } \\
\text { ECOE(e)-1D,1A }\end{array}$ & 3 & $\begin{array}{l}\text { Problem definition is } \\
\text { not stated correctly. }\end{array}$ & $\begin{array}{l}\text { Aware about the } \\
\text { problem but objectives } \\
\text { and scope not well } \\
\text { defined. }\end{array}$ & $\begin{array}{l}\text { Overall sound } \\
\text { understanding of the } \\
\text { problem and constraints. }\end{array}$ & $\begin{array}{l}\text { Problem and scope are } \\
\text { well defined to the } \\
\text { proposed work. }\end{array}$ \\
\hline & 5. & $\begin{array}{l}\text { Literature survey } \\
\text { ECOE(e)-1C }\end{array}$ & 5 & $\begin{array}{l}\text { Not reviewed any } \\
\text { related material } \\
\text { relevant to the } \\
\text { proposed work. }\end{array}$ & $\begin{array}{l}\text { Literature review/field } \\
\text { survey done, but not } \\
\text { consolidated properly. }\end{array}$ & $\begin{array}{l}\text { Literature review is done } \\
\text { and consolidated properly. }\end{array}$ & $\begin{array}{l}\text { Literature review is done } \\
\text { thoroughly highlighting } \\
\text { the importance and the } \\
\text { limitations of the } \\
\text { previous works. }\end{array}$ \\
\hline & 6. & $\begin{array}{l}\text { Identifying } \\
\text { multiple solutions } \\
\text { ECOE(e)-3A } \\
\end{array}$ & 5 & $\begin{array}{l}\text { Not developed } \\
\text { alternate solution. }\end{array}$ & $\begin{array}{l}\text { Developed few (min 3) } \\
\text { alternate solutions. }\end{array}$ & $\begin{array}{l}\text { Developed alternate } \\
\text { solutions but no } \\
\text { evaluation. }\end{array}$ & $\begin{array}{l}\text { Developed alternate } \\
\text { solutions and selection } \\
\text { of optimal solution. }\end{array}$ \\
\hline & 7 & $\begin{array}{l}\text { Selecting the best } \\
\text { suited solution } \\
\text { with justifications } \\
\text { ECOE(d)-1B }\end{array}$ & 5 & $\begin{array}{l}\text { Not developed } \\
\text { alternate solution. }\end{array}$ & $\begin{array}{l}\text { Developed few }(\min 3) \\
\text { alternate solutions but } \\
\text { selection is based on } \\
\text { arbitrary criteria }\end{array}$ & $\begin{array}{l}\text { Developed alternate } \\
\text { solutions but evaluation } \\
\text { does not consider all the } \\
\text { factors. }\end{array}$ & $\begin{array}{l}\text { Developed alternate } \\
\text { solutions and selection } \\
\text { of optimal solution } \\
\text { considering all the } \\
\text { factors. }\end{array}$ \\
\hline \multirow{5}{*}{ 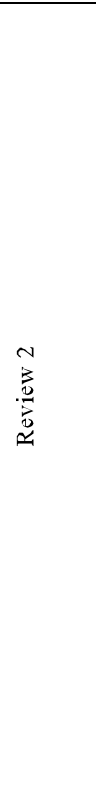 } & 1 & $\begin{array}{l}\text { Distribution of } \\
\text { work among team } \\
\text { members by leader } \\
\& \text { team work } \\
\text { ECOE(d)-1A }\end{array}$ & 5 & $\begin{array}{l}\text { Work distribution is } \\
\text { not done. }\end{array}$ & $\begin{array}{l}\text { Leader identified, but } \\
\text { work is not started }\end{array}$ & $\begin{array}{l}\text { Leader identified, but } \\
\text { work is not distributed } \\
\text { properly. }\end{array}$ & $\begin{array}{l}\text { Leader identified, but } \\
\text { work has been } \\
\text { distributed properly. }\end{array}$ \\
\hline & 2 & $\begin{array}{l}\text { Specification and } \\
\text { identification of } \\
\text { input \& output } \\
\text { ECOE(e)-2A }\end{array}$ & 5 & $\begin{array}{l}\text { Input and output are } \\
\text { not identified. }\end{array}$ & $\begin{array}{l}\text { Input and output are } \\
\text { identified. }\end{array}$ & $\begin{array}{l}\text { Input and output are } \\
\text { identified but not } \\
\text { according to specs. }\end{array}$ & $\begin{array}{l}\text { Inputs, outputs arr } \\
\text { identified and are } \\
\text { according to specs. }\end{array}$ \\
\hline & 3 & $\begin{array}{l}\text { Functional block } \\
\text { diagram relating } \\
\text { input \& output } \\
\text { ECOE(e)-2B }\end{array}$ & 5 & $\begin{array}{l}\text { Incomplete functional } \\
\text { block diagram }\end{array}$ & $\begin{array}{l}\text { Functional block } \\
\text { diagram is done but } \\
\text { inputs and outputs are } \\
\text { not stated. }\end{array}$ & $\begin{array}{l}\text { Functional block diagram } \\
\text { is done but inputs and } \\
\text { outputs are not clearly } \\
\text { mentioned. }\end{array}$ & $\begin{array}{l}\text { Functional block } \\
\text { diagram is done with } \\
\text { proper inputs and } \\
\text { outputs are } \\
\text { not clearly mentioned. }\end{array}$ \\
\hline & 4 & $\begin{array}{l}\text { Design on paper } \\
\text { with listing of the } \\
\text { required } \\
\text { components } \\
\text { ECOE(e)-2C }\end{array}$ & 5 & $\begin{array}{l}\text { Design is incomplete } \\
\text { in terms of } \\
\text { specifications and } \\
\text { sub-blocks. }\end{array}$ & $\begin{array}{l}\text { Design of sub blocks is } \\
\text { satisfactory. }\end{array}$ & $\begin{array}{l}\text { Design is completed in } \\
\text { line with the } \\
\text { specifications required. }\end{array}$ & $\begin{array}{l}\text { Design is complete, with } \\
\text { all functional blocks in } \\
\text { working condition. }\end{array}$ \\
\hline & 5 & $\begin{array}{l}\text { Simulation of the } \\
\text { design using any } \\
\text { open source } \\
\text { ECOE(c-2D) }\end{array}$ & 5 & $\begin{array}{l}\text { No results and no } \\
\text { analysis }\end{array}$ & $\begin{array}{l}\text { Partial results but no } \\
\text { analysis. }\end{array}$ & Inadequate analysis & $\begin{array}{l}\text { Desired results are } \\
\text { obtained and analyzed. }\end{array}$ \\
\hline 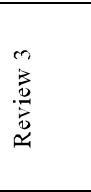 & 1 & $\begin{array}{l}\text { Detailed block } \\
\text { diagram with all } \\
\text { specifications/ } \\
\text { algorithms } \\
\text { ECOE(e)-5A }\end{array}$ & 10 & $\begin{array}{l}\text { Incomplete block } \\
\text { diagram }\end{array}$ & $\begin{array}{l}\text { Functional block } \\
\text { diagram is done but } \\
\text { improper } \\
\text { interconnections of } \\
\text { block. }\end{array}$ & $\begin{array}{l}\text { Functional block diagram } \\
\text { is done with proper } \\
\text { interconnections of block } \\
\text { but not according to } \\
\text { specs. }\end{array}$ & $\begin{array}{l}\text { Functional block } \\
\text { diagram is done with } \\
\text { proper interconnections } \\
\text { of } \\
\text { blocks according to } \\
\text { specs. }\end{array}$ \\
\hline
\end{tabular}




\begin{tabular}{|c|c|c|c|c|c|c|c|}
\hline & 2 & $\begin{array}{l}\text { Integrating the } \\
\text { functional blocks, } \\
\text { debugging details } \\
\text { and } \\
\text { Partial } \\
\text { demonstration of } \\
\text { results } \\
\text { ECOE(c- } \\
\text { 2B,C,D,E) }\end{array}$ & 10 & $\begin{array}{l}\text { Functional blocks are } \\
\text { not identified. } \\
\text { No results }\end{array}$ & $\begin{array}{l}\text { Functional blocks are } \\
\text { implemented but } \\
\text { improperly integrated } \\
\text { Code/Simulation } \\
\text { results are not proper. }\end{array}$ & $\begin{array}{l}\text { Functional blocks are } \\
\text { implemented with proper } \\
\text { integration. } \\
\text { Code/Simulation results } \\
\text { are proper but unable to } \\
\text { demonstrate. }\end{array}$ & $\begin{array}{l}\text { Proper integration of } \\
\text { functional blocks and } \\
\text { debugging details are } \\
\text { provided. } \\
\text { Able to demonstrate the } \\
\text { required result. }\end{array}$ \\
\hline & 3 & $\begin{array}{l}\text { Draft of the work } \\
\operatorname{ECOE}(\mathrm{g})-2 \mathrm{C}\end{array}$ & 5 & Not done & partial & Incomplete & Done \\
\hline \multirow{4}{*}{$\begin{array}{l}+ \\
3 \\
0 \\
0 \\
0 \\
0 \\
\end{array}$} & 1 & $\begin{array}{l}\text { Hardware/product } \\
\text { implementation, } \\
\text { ECOE(e)-5C }\end{array}$ & 10 & No results & $\begin{array}{l}\text { Hardware } \\
\text { implementation results } \\
\text { are not proper. }\end{array}$ & $\begin{array}{l}\text { Hardware implementation } \\
\text { results are proper but } \\
\text { unable to demonstrate. }\end{array}$ & $\begin{array}{l}\text { Implementation done } \\
\text { and demonstration of } \\
\text { desired results. }\end{array}$ \\
\hline & 2 & $\begin{array}{l}\text { Analysis \& } \\
\text { demonstration of } \\
\text { results of results } \\
\text { ECOE(e)-5B }\end{array}$ & 5 & $\begin{array}{l}\text { Design is incomplete } \\
\text { in terms of specifications } \\
\text { and sub-blocks. No results } \\
\text { and no analysis }\end{array}$ & $\begin{array}{l}\text { Design of sub blocks is } \\
\text { satisfactory, partial } \\
\text { results but no analysis. }\end{array}$ & $\begin{array}{l}\text { Design is completed in } \\
\text { line with the } \\
\text { specifications required. } \\
\text { Inadequate analysis. }\end{array}$ & $\begin{array}{l}\text { Design is complete, with } \\
\text { all functional blocks in } \\
\text { working condition. } \\
\text { Desired results are } \\
\text { obtained and analyzed. }\end{array}$ \\
\hline & 3 & $\begin{array}{l}\text { Report submission } \\
\text { in Latex (as given } \\
\text { in the format) } \\
\mathbf{E C O E}(\mathbf{g})-\mathbf{1 A}, \mathbf{B}\end{array}$ & 5 & $\begin{array}{l}\text { Not followed the } \\
\text { recommended format }\end{array}$ & $\begin{array}{l}\text { Followed the format } \\
\text { but the contents are not } \\
\text { properly organized }\end{array}$ & $\begin{array}{l}\text { Format and contents are } \\
\text { satisfactory }\end{array}$ & $\begin{array}{l}\text { The report is properly } \\
\text { organized as per the } \\
\text { recommended format. }\end{array}$ \\
\hline & 4 & $\begin{array}{l}\text { Paper } \\
\text { presentations, } \\
\text { awards. } \\
\mathbf{E C O E}(\mathbf{g})-\mathbf{2 B}, \mathbf{C}\end{array}$ & 5 & Nil & $\begin{array}{l}\text { Paper not applied for } \\
\text { the conference, not } \\
\text { selected }\end{array}$ & $\begin{array}{l}\text { Paper applied for the } \\
\text { conference and selected }\end{array}$ & $\begin{array}{l}\text { Paper applied for the } \\
\text { conference and awarded. }\end{array}$ \\
\hline
\end{tabular}

\begin{tabular}{|c|c|c|c|c|c|c|}
\hline & Rubrics & $\begin{array}{c}\text { Mar } \\
\text { ks }\end{array}$ & $\begin{array}{l}\text { Inadequate } \\
\text { Upto } 25 \%\end{array}$ & $\begin{array}{l}\text { Average } \\
\text { Upto } 50 \%\end{array}$ & $\begin{array}{l}\text { Admirable } \\
\text { Upto } 75 \%\end{array}$ & $\begin{array}{l}\text { Outstanding } \\
\text { Upto } 100 \%\end{array}$ \\
\hline \multirow{5}{*}{ 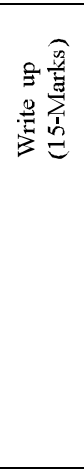 } & $\begin{array}{l}\text { Problem } \\
\text { definition }\end{array}$ & 2 & Objectives are not clear. & $\begin{array}{l}\text { Objectives and scope are not } \\
\text { well defined. }\end{array}$ & $\begin{array}{l}\text { Objectives clearly framed. } \\
\text { Scope not well defined. }\end{array}$ & $\begin{array}{c}\text { Objectives are correctly } \\
\text { Stated. }\end{array}$ \\
\hline & Block diagram & 3 & Not given & Partial block diagram & $\begin{array}{c}\text { Block diagram but } \\
\text { incomplete } \mathrm{i} / \mathrm{p} \text { and } \mathrm{o} / \mathrm{p}\end{array}$ & $\begin{array}{l}\text { Complete block diagram } \\
\text { with proper } \mathrm{i} / \mathrm{p} \text { and } \mathrm{o} / \mathrm{p} \text {. }\end{array}$ \\
\hline & $\begin{array}{l}\text { Individual } \\
\text { contribution to } \\
\text { project }\end{array}$ & 3 & $\begin{array}{l}\text { Work distribution is not } \\
\text { done. }\end{array}$ & $\begin{array}{l}\text { Leader identified, but work } \\
\text { is not started }\end{array}$ & $\begin{array}{l}\text { Leader identified, but } \\
\text { work is not distributed } \\
\text { properly. }\end{array}$ & $\begin{array}{l}\text { Leader identified, but } \\
\text { work has been } \\
\text { distributed properly. }\end{array}$ \\
\hline & $\begin{array}{l}\text { Budget for the } \\
\text { project }\end{array}$ & 2 & $\begin{array}{l}\text { Marketing Survey not } \\
\text { done }\end{array}$ & $\begin{array}{l}\text { Marketing survey is done } \\
\text { but budgeting not done. }\end{array}$ & $\begin{array}{l}\text { Marketing survey and } \\
\text { budgeting are done. }\end{array}$ & $\begin{array}{l}\text { Proper allocation of } \\
\text { budgeting done }\end{array}$ \\
\hline & \begin{tabular}{|c|} 
Application of \\
project in societal \\
context
\end{tabular} & 5 & $\begin{array}{c}\text { Not aware of the social } \\
\text { context }\end{array}$ & $\begin{array}{l}\text { Application of the project } \\
\text { not defined }\end{array}$ & $\begin{array}{l}\text { Application of the } \\
\text { project defined but not } \\
\text { in social context }\end{array}$ & $\begin{array}{l}\text { Application of the } \\
\text { project defined with } \\
\text { reference to social } \\
\text { context }\end{array}$ \\
\hline \multirow[b]{2}{*}{ 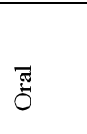 } & $\begin{array}{c}\text { PPT } \\
\text { preparation }\end{array}$ & 5 & Not prepared & Incomplete Preparation & $\begin{array}{l}\text { Prepared but flow not } \\
\text { maintained }\end{array}$ & $\begin{array}{l}\text { Prepared with proper } \\
\text { flow }\end{array}$ \\
\hline & $\begin{array}{c}\text { PPT } \\
\text { Presentation }\end{array}$ & 5 & Not prepared & Incomplete Preparation & $\begin{array}{l}\text { Presented but flow is } \\
\text { not maintained }\end{array}$ & $\begin{array}{l}\text { Presented with effective } \\
\text { communication }\end{array}$ \\
\hline 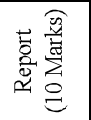 & $\begin{array}{c}\text { Written } \\
\text { presentation }\end{array}$ & 10 & $\begin{array}{l}\text { Not followed the } \\
\text { recommended format }\end{array}$ & $\begin{array}{c}\text { Followed the format but the } \\
\text { contents are not properly } \\
\text { organized }\end{array}$ & $\begin{array}{c}\text { Format and contents are } \\
\text { satisfactory }\end{array}$ & $\begin{array}{l}\text { The report is properly } \\
\text { organized as per the } \\
\text { recommended format. }\end{array}$ \\
\hline \multirow[t]{3}{*}{ 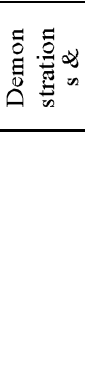 } & $\begin{array}{c}\text { Overall } \\
\text { Explanation }\end{array}$ & 5 & Not prepared & $\begin{array}{l}\text { Prepared but not well } \\
\text { explained }\end{array}$ & $\begin{array}{l}\text { Explained but not } \\
\text { effectively. }\end{array}$ & $\begin{array}{l}\text { Explained with } \\
\text { effective } \\
\text { communication }\end{array}$ \\
\hline & $\begin{array}{l}\text { Demonstration } \\
\text { of results }\end{array}$ & 5 & $\begin{array}{l}\text { Design is incomplete in } \\
\text { terms of specifications and } \\
\text { sub-blocks. }\end{array}$ & $\begin{array}{l}\text { Design of sub blocks is } \\
\text { satisfactory, }\end{array}$ & $\begin{array}{l}\text { Design is completed in } \\
\text { line with the } \\
\text { specifications required. }\end{array}$ & $\begin{array}{l}\text { Design is complete, } \\
\text { with all functional } \\
\text { blocks in working } \\
\text { condition. }\end{array}$ \\
\hline & $\begin{array}{l}\text { Analysis of } \\
\text { results }\end{array}$ & 5 & No results and no analysis & $\begin{array}{l}\text { Partial results but no } \\
\text { analysis. }\end{array}$ & Inadequate analysis. & $\begin{array}{l}\text { Desired results are } \\
\text { obtained and } \\
\text { analyzed. }\end{array}$ \\
\hline
\end{tabular}




\subsection{Criteria for team formation}

The following criteria's are defined for the student's group formation

i. 2 to 4 students in a team.

ii. Role of a teammates: Project manager Software manager and Hardware manager

iii. Teams will be formed by the faculty and Head of the department.

\subsection{Role of a Guide}

The primary responsibility of the guide is to help students to understand the meaning and need of various stages in the implementation of the project. At every stage of the project development, guide should help towards its successful completion as per the predefined standards.

\subsection{Steps for the students to carry out a project:}

i. Define the problem

ii. Specify the requirements

iii. Specify the design in the understandable form (Block Diagram, Flowchart, Algorithm, etc)

iv. Analyze the design

v. Select appropriate simulation tool and development board for the design.

vi. Implement the design

vii. Result representation and analysis

viii. Prepare a document and presentation according to the format given

\section{Evaluation Scheme}

Evaluation is done based on the rubrics given in Table 1 and 2. This is under two phases. They are continuous evaluation scheme (CIE) and semester end evaluation scheme(SEE). The Table 1 and 2 shows the rubrics and marks distribution for the CIE and SEE. These rubrics are based on the engineering design process.

3.1 Continuous internal evaluation (CIE) and semester end evaluation (SEE)

i. Project shall be reviewed and evaluated by the concerned Guide once in a week for $50 \%$ of the marks. ii. Project shall be evaluated by the review committee, once in a month for $50 \%$ of the marks

The comparisons of the credits distribution for the year 2014-1015 is as shown in Table 3. This is the major change in curriculum and led to the promotion of co-curricular activities.

Table 3: comparison of the credits distribution

\begin{tabular}{|l|c|}
\hline Year & Credits distribution \\
\hline 2014 & 3 \\
\hline 2015 & 6 \\
\hline
\end{tabular}

\section{Outcomes}

The course project outcome is measured w.r.to the rubrics designed as shown in Table 1. The tremendous increase in the participation of co-curricular activities is achieved. Table 4 shows the comparison of participation in co-curricular activities for the year 2015-2014. The data shows the increase in state level and national level participation.

Table 4. Comparison of participation in co-curricular activities for the year 2015- 2014.

\begin{tabular}{|l|c|c|c|c|c|}
\hline Year & $\begin{array}{l}\text { Number } \\
\text { of } \\
\text { batches }\end{array}$ & $\begin{array}{l}\text { Number } \\
\text { of awards } \\
\text { won }\end{array}$ & $\begin{array}{l}\text { Perce } \\
\text { ntage }\end{array}$ & $\begin{array}{l}\text { State } \\
\text { level }\end{array}$ & $\begin{array}{l}\text { National } \\
\text { level }\end{array}$ \\
\hline $2011-15$ & 40 & 6 & $15 \%$ & 5 & 1 \\
\hline $2012-16$ & 40 & 26 & $65 \%$ & 7 & 7 \\
\hline
\end{tabular}

In automotive sector out of 22 batches, 15 of them won the prize in various categories as listed below.

i. Paper presentation at Gauhati university and Pleiades 2015

ii. 8 papers selected at Sristi-15, Bangalore

iii. 1st prize in VERVE held by ISSATE, Bangalore

iv. Four of the projects at KPIT SPARKLE

A. Medical - (2 project batches out of 4$)$

i. SRISHTI-15 project exhibition

B. Assistive - (5 project batches out of 8 )

i. IEECE conference, Kochi, paper presentation and Pleiades-15

ii. Avishkar conducted by SRISHTI-15, 2nd place

iii. Idea impact in SRISHTI-15, 3rd place

iv. Paper at BITS, won 3rd prize

C. VLSI-(4 project batches out of 6)

i. Two papers at SRISHTI-15, Bangalore 
ii. A project at International conference, Don Bosco, Bangalore, won 3rd prize

iii. Paper presentation at NSMT-2015, Suratkal

Figure 3 shows the mapping of outcome elements with the rubrics. The evaluation scheme is designed as shown in Table 1. The focus is on outcome c,e,f and g. In review 1 the highest score is 8.1 for need analysis and alternate solutions. and the least score is 6.9 for literature survey. In review 2 the highest score is for functional block diagram and the least is for distribution of work among team members. In review 3 the highest score is for detailed block diagram and the least is for draft of the work. In review 4 highest is for Analysis of results and the least is for paper Presentations and awards.

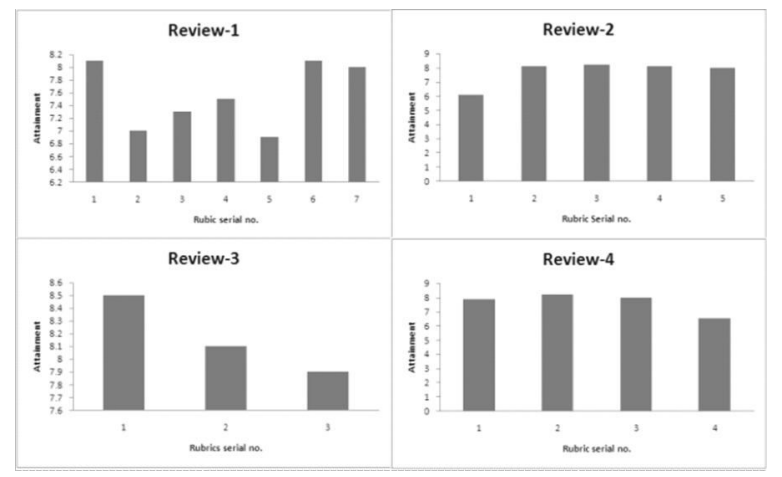

Figure 3: Outcome measurement for review 1,2,3 and 4

\section{Conclusion}

Theme based Minor projects course with 6 credits introduced in the pre final year students of 2011-15 batch. Students have followed engineering design process in implementation of the projects. The rubrics are redesigned to asses the student's projects. Students are encouraged to participate in various competations held across the country. With this practice, we achieved $65 \%$ participation in co-curricular activity.

\section{References}

[1] Ball, S. (2004), 'Education reform as social Barberism: economism and the end of authenticity', Scottish Educational Review, 37
(1): 4-16. Stirling: University of Stirling

[2] Ball, S. (2007), Education Plc: Understanding Private Sector Participation in Public Sector Education, London: Routledge

[3] Bash, L. (2005), 'Teaching and the globalization of knowledge', in D. Coulby and E. Zambeta (eds.) World Yearbook of Education 2005.

[4] Globalisation and Nationalism in Education, London: Routledge Biesta, G.J.J. (2004), 'Education, accountability, and the ethical demand; can the democratic potential of accountability be regained', Educational Theory, 54:233-250. Illinois: University of Illinois

[5] Bottery, M. and Wright, N. (2000), Teachers and the State: towards a directed profession, London: Routledge

[6] Crozier,G. \& Reay D. (eds.) (2005), Activating Participation: mothers, fathers and teachers working towards partnership, Stoke-on-Trent and USA,VA: Stylus Publishing: Trentham Books Day, C. and Sachs, J. (eds.) (2004),

[7] http://www.method $123 . \mathrm{com} / \mathrm{project}$ lifecycle.php

[8] Shapin, S., \& Shaffer, S. (1985). Leviathos and the airpump. Princeton: Princeton University Press.

[9] Davis, B.D and Miller, T.R. (1996). 'Job preparation for the 21st century: A group project learning model to teach basic workplace skills', Journal of Education for Business 72(2), 69-74.***

[10] Dewey, J. (1933). How We Think. A Restatement of the Relation of Reflective Thinking to the Educative Process. Boston: D.C. Heath. Dillenbourg, P. (1999). 'Introduction: What do you mean by "collaborative learning"?'

[11] Dillenbourg, P. (ed.), Collaborative Learning. Cognitive and Computational Approaches. Amsterdam: Pergamon, pp. 1-19. 